har tilrettelagt veien for nanorevolusjonen. Den underholdende og samtidig spennende formidlingen får en til å se med nye øyne på den kunnskapen i fysikk og kjemi som man har med seg fra studiedagene.

Den leseren som er mer interessert i det man har oppnådd med nanoteknologien, hopper direkte til den andre delen av boken. Her presenteres vitenskap der man allerede har tatt i bruk nanoteknologien. Temaer som drikkevann, energiproduksjon og nanomedisin dekkes. Spesielt innen det medisinske fagfeltet tydeliggjør forfatteren hvilke muligheter nanoteknologien gir, og hvilke utfordringer den fører med seg.

Til tross for at Jan Sire er positiv til den nanoteknologiske revolusjonen, hevder han med gode og overbevisende grunner at den nye teknologien også kan bli farlig.

Boken er lett å forstå og morsom å lese. Den klare og oversiktlige disposisjonen gir leseren en mulighet til å fokusere på de delene som er interessante. Den åpner øynene våre og forbereder oss på den nært forestående nanorevolusjonen.

\section{Hans-Hermann Gerdes}

Institutt for biomedisin

Universitetet i Bergen

\section{Slaget og veien til mestring}

Løvhaug P.

Det levende buret

91 s. Sandnes: Commentum forlag, 2009.

Pris NOK 248

ISBN 978-82-823-3020-6

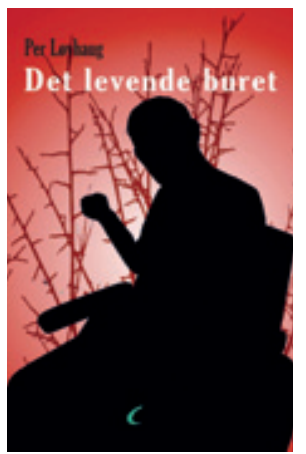

Forfatteren har arbeidet i medieverden hele sitt liv, som journalist i aviser og i NRK og som forfatter. Da han var 69 år, ble han rammet av en alvorlig hjerneblødning og lå bevisstløs på sykehus i tre uker. I denne tiden hadde han en forferdelig drøm som kom igjen hele tiden. Han drømte at han lå i et bur av levende jernstenger som klistret seg til kroppen hans. Langsomt ble han litt bedre, med litt fremgang og stadige tilbakeslag. Han kjempet seg langsomt fremover på tross av sterk invaliditet, fortvilelse og innimellom håpløshet. Det var først sykehus og bare pleie, så rehabilitering, og til slutt kom han hjem til kårboligen på småbruket, den trofaste konen og kommunens hjemmesykepleiere. Han opplevde noen enestående hjelpere, men også en strøm av stadig nye hjelpere som bare var på jobb. Innimellom ble alt håpløst, og han drømte om døden. Han tenkte at han kunne jo bare bli liggende, slutte å spise og vente på døden - som mange gamle på sykehjem. Han drømte også om aktiv dødshjelp. Men han ville ikke gi seg, og han bar også på en annen drøm, nemlig å begynne å skrive igjen.

Slik ble denne lille boken til. Den består av en serie korte kapitler på en side eller to. Hvert kapittel skildrer et problem på den lange veien til mestring. Underveis fikk han også en ny hjerneblødning som rammet balansenerven, og han måtte kjempe mot en overveldende svimmelhet. Det virker utrolig at han ikke ga opp. Det skyldtes hans nesten ufattelige gåpåhumør, en trofast kone og familie, noen gode hjelpere og drømmen om å skrive denne lille boken til hjelp for andre pasienter. Nå er det gått tre år. Han har fremdeles en stor invaliditet og trenger mye hjelp. Heldigvis har han også fått en personlig assistent fra kommunen, slik at kona får litt fri noen timer i uken.

Boken beskriver hans tunge vei til mestring. Han forteller om håp og fortvilelse og om gode hjelpere, men også om dårlige systemer, særlig i kommunehelsetjenesten. Han roser sin trofaste familie, og han viser en innbitt vilje til ikke å gi opp, til å kjempe seg til mestring.

Drømmen var å skrive en bok som kunne hjelpe ham selv og andre, både pasienter, pårørende og personell. Jeg synes han har klart det på en imponerende måte. Språket er klart og godt og preget av et liv som journalist. Tankene er klare og viktige, og jeg har ingen kritiske spørsmål. Jeg vil ønske forfatteren til lykke, og jeg håper han får mange lesere - for det fortjener han.

Peter F. Hjort

Blommenholm

\section{Jevnt godt}

Hauge R.

Rus og rusmidler gjennom tidene

253 s. Oslo: Universitetsforlaget, 2009

Pris NOK 329

ISBN 978-82-15-01543-9

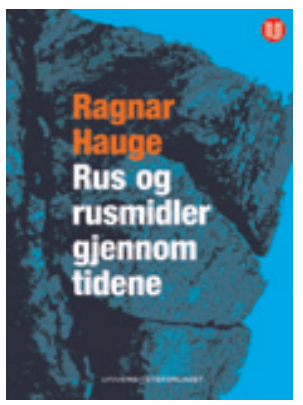

Forfatteren er jurist og har arbeidet $i$ en årrekke ved Statens institutt for rusmiddelforskning (Sirus), der han i flere år også var instituttleder. Boken er skrevet slik at den kan forstås av de fleste, men det er nok de som arbeider innenfor dette feltet som vil ha mest nytte av den.
Det gis et inngående bilde av rusmidlene og deres bruk gjennom tidene. I fire hovedkapitler omfattes dempende stoffer som opiater, cannabis, alkohol samt barbiturater og løsemidler, oppkvikkende stoffer som kokain, tobakk, kaffe og amfetamin og hallusinogene stoffer. Til slutt omtales nye rusmidler og ungdomskulturen.

Av særlig interesse er forfatterens omtale av rusmidlenes bruk i andre kulturer enn vår vestlige. Islams totalforbud mot alkohol er velkjent, men også hinduismen, buddhismen og de kinesisk-religiøse trosretninger har hatt krav om totalavhold - eller måtehold, som innen jødedommen. For muslimer gjelder forbudet også narkotiske stoffer, selv om opium og cannabis var i utstrakt bruk i enkelte islamske land helt frem til slutten av 1970-årene. Iran har i dag faktisk verdens høyeste forbruk av opium.

Fra 1980-årene var det først og fremst heroinbruken blant de langtkomne misbrukerne som fanget oppmerksomheten. På denne tiden fikk metylendioksimetamfetamin (MDMA), senere kalt ecstasy, innpass i USA og noe senere i Europa. I 1990årene ble såkalte «houseparties» eller «raves» populære, der hundrevis av ungdommer kunne komme sammen til langvarig dans med teknomusikk og flimrende lyseffekter. Ecstasy var der det sentrale rusmidlet. Samtidig fikk kokain, som hadde vært ukjent i ungdomsmiljøet, innpass, til dels også gammahydroksybutyrat (GHB) og benzodiazepiner. Av disse fikk særlig Rohypnol rykte på seg som et «voldtektsstoff». Housemiljøet fikk som hippiemiljøet 30 år tidligere, en relativt kort blomstringstid og var i stor grad borte ved inngangen til 2000-årene.

Verket er historisk. Likevel kunne det vært ønskelig å høre forfatterens mening om dagens situasjon og hva vi kan vente oss i fremtiden. Hva med stoffenes geopolitiske betydning og hva med den omfattende narkohandelen? Som jurist og ekspert på rusmidler, ville jeg tro at Hauge har gjort seg sine tanker om dette.

Litteraturlisten er omfattende, men av de over 300 referansene er bare et fåtall fra det siste tiåret. Forfatteren har ikke fått med seg de mer alvorlige skadevirkningene av cannabis som synes å bli mer og mer overbevisende dokumentert. Saksregisteret dreier seg bare om psykoaktive stoffer og burde vært utvidet til et vanlig temaregister.

\section{Einar Kringlen}

Psykiatrisk institutt

Universitetet i Oslo 